\title{
Cikkismertetés: Segít-e, ha a pénztáraknál kínált ropogtatnivalókat egészségesebbre cserélik?
}

\author{
Article review: Is it helpful to change the snacks to healthier \\ at the checkout counters?
}

Ismertető: $\quad$ Devosa Iván $\bigotimes$

Neumann János Egyetem, Pedagógusképző Kar, Egészségtudományi és Egészségfejlesztési

Kutatócsoport, Kecskemét

Ismertetett cikk: Huitink, M., Poelman, M., Seidell, J.C. et al. Can unhealthy food purchases at checkout counters be discouraged by introducing healthier snacks? A real-life experiment in supermarkets in deprived urban areas in the Netherlands. BMC Public Health 20, 542 (2020). https://doi.org/10.1186/s12889-020-08608-6

Beküldve: $\quad$ 2020. 05. 15 .

doi: $\quad$ 10.24365/ef.v61i3.600

Kulcsszavak: vásárlói viselkedés; ropogtatnivalók; Impulzív viselkedés

Keywords: purchaser behaviour; snacks; impulsive behaviour

\section{HÁTTÉR}

A szupermarketekben a pénztár melletti árubemutató polcok a vásárlók számára elkerülhetetlen helyszín, ahol nagy valószínűséggel impulzív élelmiszer-vásárlásokra kerül sor. Sajnálatosan az itt kihelyezett élelmiszerek túlnyomórészt egészségtelenek. Ebben a kísérletben azt vizsgálták, hogy a hollandiai hátrányos helyzetû városok szupermarketjeiben a pénztáraknál választott egészségtelen élelmiszerek vásárlási arányát csökkentik-e az Egészséges Pénztár (Healthy Checkout Counter, HCC) bevezetésével. Emellett azt is vizsgálták a kutatók, hogy mi a vásárlók egyéni véleménye a HCC-vel kapcsolatban.

\section{MÓDSZER}

A HCC bevezetése egy vezető hollandiai áruházlánc kezdeményezése volt, amely a gyakorlatban azt jelentette, hogy a pénztárainál egészségesebb ropogtatnivalókat tartalmazó árubemutató polco- kat helyezett ki. A kutatás során 15 próba- és 9 kontrollszupermarkettel múködtek együtt a kutatók. Három próbaszupermarketben a fentieken túl keresztmetszeti vásárlói értékelést is végeztek: szóbeli kikérdezéssel vizsgálták a vásárlók HCC-vel kapcsolatos véleményét ( $n=134$ fö). Azt, hogy mennyi volt az eladott egészségtelen és egészségesebb ropogtatnivalók mennyisége a pénztáraknál, az eladási adatok feldolgozásával mérték. A kutatási időszak kétszer 8 hétre tagolódott: kontrollidőszak, amikor a HCC még nem került az üzletekben bevezetésre (2015. szeptembere és októbere), illetve a próbaidőszak, a HCC-k alkalmazásával (2015 novembere és decembere).

\section{EREDMÉNYEK}

Kontrollidőszak alatt a vásárlók 100 főre vetítve átlagosan 1,9 (szórás: 0,1), míg próbaidőszak alatt $1,7(0,08)$ egészségtelen ropogtatnivalót vásároltak a próbaszupermarketekben, ami 0,2 csökkenést jelent az eladásokban. Ezzel párhuzamosan a 
kontrollszupermarketekben a kezdeti $1,5 \quad(0,1)$ eladási szám a próbaidőszak alatt $1,4(0,10)$ eladásra csökkent, ami 0,1 csökkenésnek felel meg. [1. ábra] A lineáris regressziós elemzések nem mutattak ki statisztikailag szignifikáns különbséget az egészségtelen ropogtatnivalók értékesítési adataiban a vizsgált próba- és kontrollszupermarketek között a két időszakban ( $\beta=-0,008,95 \%$, $\mathrm{Cl}=-0,15-0,14)$. A megvásárolt egészségesebb ropogtatnivalók átlagos mennyisége a próbaszupermarketekben 100 vásárlónként $0,2(0,3)$ volt a vizsgálati időszak alatt. A próbaszupermarketekben vásárlók 41\%-a vette észre a HCC-t, és $80 \%$-uk elégedett vagy nagyon elégedett volt a fejlesztéssel.

\section{KÖVETKEZTETÉSEK}

A szupermarketekben végezett kísérlet feltárta, hogy az egészségesebb élelmiszerek kihelyezése a pénztáraknál önmagában nem vezetett ahhoz, hogy a vásárlók az egészségtelen ropogtatnivalókat egészségesebb alternatívákkal felváltsák. Jóllehet a szupermarketek vásárlói pozitívan értékelték a HCC-t, további vizsgálatokra lesz szükség az egészségesebb élelmiszer-vásárlások ösztönzésére irányuló további stratégiák kidolgozásához és bevezetéséhez a szupermarketekben.

1. ábra: Az egészségtelen ropogtatnivalók eladási adatainak változásai a kontroll- és a próbaidőszakban a próba-és a kontrollszupermarketekben

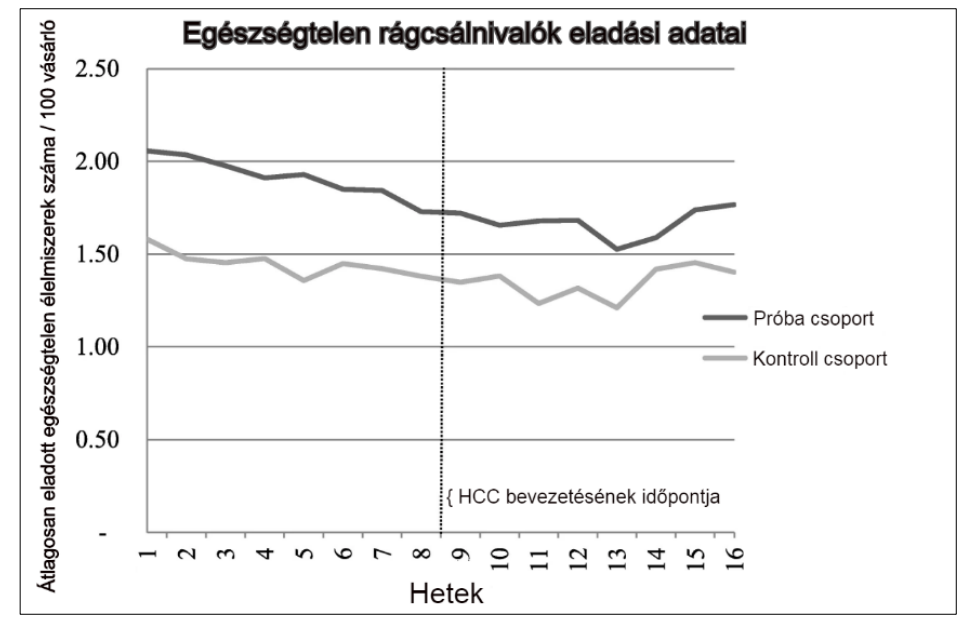

Forrás: saját szerkesztés az eredeti változat alapján

\section{TANULSÁGOK A HAZAI SZAKEMBEREK SZÁMÁRA}

A hollandiai HCC kutatás eredményei Magyarországon is hasznosithatóak, azonban önmagában kevés, ha előírjuk a különböző termékeket hol helyezhetik ki az üzleten belül a kereskedők: a kizárólag ezzel a módszerrel elért eredmények nem elégségesek ahhoz, hogy mélyreható és tartós változást eredményezzenek a vásárlói szokásokban. A fenti tanulmány is megerősíti, hogy további anyagi eszközök szükségesek az egészséges élelmiszerek fogyasztásának ösztönzésére, mind ezen élelmiszerek ártámogatása (akár ÁFA csökkentés), illetve az egészségtelen alternatívák árának emelése (akár NETA emelés) útján.

\section{KÖSZÖNETNYILVÁNITÁS}

Köszönettel tartozom a publikáció elkészítésének támogatásáért, amely az EFOP-3.6.1-16-2016-00006 „A kutatási potenciál fejlesztése és bővítése a Neumann János Egyetemen” pályázat keretében valósult meg. A projekt a Magyarország és az Európai Unió támogatásával, az Európai Szociális Alap társfinanszírozásával, a Széchenyi 2020 program keretében valósul meg. 